\title{
Using RAP Strategy to Teach Reading Comprehension in EFL Class
}

\author{
I Kadek Agus Sudarmawan ${ }^{1 *}$ iD \\ ${ }^{l}$ English Education Department, Ganesha University of Education, Singaraja, Indonesia
} *Corresponding author: agusudarmawan98@gmail.com

\section{Abstrak}

Kemampuan membaca siswa di Indonesia masih rendah. Kurangnya pemahaman membaca siswa umumnya disebabkan oleh tidak efektifnya strategi yang digunakan guru dalam mengajar membaca. Siswa hanya melakukan silent reading dan diminta menjawab pertanyaan dari teks. Penelitian ini bertujuan untuk menganalisis penggunaan strategi RAP untuk mengajar pemahaman membaca di kelas EFL. Jenis penelitian ini adalah kualitatif. Penelitian ini dirancang dalam bentuk studi kepustakaan atau studi kepustakaan. Sumber data diambil dari buku elektronik (e-book), artikel penelitian, dan sumber lain yang relevan. Data yang terkumpul kemudian dianalisis melalui analisis data kualitatif. Kegiatan analisis data dilakukan secara interaktif, dan tahap keempat adalah pengumpulan data, reduksi data, penyajian data, dan inferensi/verifikasi. Hasil penelitian adalah strategi RAP dapat membantu siswa untuk meningkatkan memori tentang gagasan utama dan rincian teks tertentu, strategi membaca interaktif yang menawarkan banyak manfaat bagi siswa dalam kegiatan membaca dapat membantu siswa dalam memahami teks serta pemahaman bacaan mereka, menawarkan kesempatan kepada siswa untuk mempraktikkan konten, dan dapat dilakukan dengan cepat oleh guru di kelas membaca. Dapat disimpulkan bahwa strategi RAP merupakan strategi yang tepat yang dapat digunakan guru untuk mengajar membaca di kelas.

Kata kunci: Strategi RAP, Pemahaman Membaca, EFL

\section{Abstract}

The reading ability of students in Indonesia is still low. The lack of students' reading comprehension is generally caused by ineffective strategies used by teachers in teaching reading. Students only do silent reading and are asked to answer questions from the text. This study aims to analyze the use of the RAP strategy to teach reading comprehension in EFL classes. This type of research is qualitative. This research is designed in the form of a literature study or literature study. Sources of data are taken from electronic books (e-books), research articles, and other relevant sources. The collected data is then analyzed through qualitative data analysis. Data analysis activities are carried out interactively, and the fourth stage is data collection, data reduction, data presentation, and inference/verification. The results of the study are that RAP strategies can help students to improve memory about the main ideas and details of specific texts, interactive reading strategies that offer many benefits for students in reading activities can help students in understanding texts as well as their reading comprehension, offering students opportunities to practice content, and can be done quickly by the teacher in the reading class. It can be concluded that the RAP strategy is the right strategy that teachers can use to teach reading in the classroom.

Keywords: RAP Strategy, Reading Comprehension, EFL

$\begin{array}{lll}\text { History: } & & \text { Publisher: Undiksha Press } \\ \text { Received } & \text { : February 10, } 2021 & \text { Licensed: This work is licensed under } \\ \text { Revised } & \text { : February 12, } 2021 & \text { a Creative Commons Attribution 3.0 License } \\ \text { Accepted } & \text { : April 03, 2021 } & \text { PC C) OP }\end{array}$

\section{Introduction}

Reading is one of the crucial aspects of language learning. It is an essential skill since it helps students to acquire knowledge. Reading can improve the general English language skills of the students, namely, vocabulary, speaking and writing skills, ideas, facts, and students' experience experience (Lai, Chen, \& Lee, 2019; Szanto, 2020). Reading is the foundation of all learning processes in today's classroom (Afrianti \& Wirman, 2020; Muhammad, Sholichah, \& Aziz, 2019; Warsihna, 2016). It means that the other language skills such as listening, speaking, and students will not comprehend writing without reading. In other words, students will face difficulties in acquiring any subjects if they have a low 
reading literacy level. Therefore, reading is essential for students because it will help their language acquisition (Asna \& Mimi, 2016; Pertiwi, Sumarno, \& Dwi, 2019).

The ability of students to understand the content of the text is the primary goal of reading in language learning. Reading for understanding is the primary goal of reading itself (Asna \& Mimi, 2016; Astuti \& Istiarini, 2020). However, understanding the message or intent of the text is not easy and becomes a problem for students. According to the Program for International Student Assessment or PISA, students' reading ability in Indonesia is still low. Indonesia is ranked 72 out of 77 countries with a score of 371 of the OECD countries' average reading ability of 487 (Astuti \& Istiarini, 2020). It means that students' reading comprehension level in Indonesia is still far from the competency standard or expected. Most Indonesian students have difficulty understanding the meaning of sentences, objectives, main ideas, and specific ideas of the text (Fitri, 2019; Rasyid \& Asrori, 2013). Understanding textual references from a text is also a problem for students and identifying the primary and specific ideas of the text itself (Suwana, Artini, \& Piscayanti, 2013).The lack of students' reading comprehension is generally caused by ineffective strategies used by teachers in teaching reading (Anjani, Dantes, \& Artawan, 2019; Maryani, Ichsan, \& Khairunnisa, 2017; Pertiwi et al., 2019). Students only do silent reading and are asked to answer questions from the text. This means that the teacher does not provide interesting strategies that improve students' reading comprehension. Therefore, the right strategy is needed by teachers in teaching reading in the classroom.

To the problems above, teachers need to use exciting reading strategies that encourage students' reading comprehension. There are many strategies that can be used by teachers in teaching reading, one of which is the RAP strategy. RAP strategy stands for Read, Ask and Put strategy. A paraphrasing strategy consisting of three steps: "Read the paragraph intensively, Ask yourself what the main idea and specific ideas or details are and Put the ideas into your own words." Furthermore, they argue that the RAP strategy is an effective strategy that can improve students' reading comprehension (Surayatika, 2018; Suwana et al., 2013). In practice, students will decode the text, but they will carry out other activities in their reading, such as doing analysis, inferring the meaning of the text, and paraphrasing or pouring the ideas they get from the text into their own words. This strategy promotes a more profound understanding process and allows students to perform and achieve better in their reading (Dahlani \& Rahman, 2016; Ni'matuzahroh, 2015). Prosedur The paraphrasing procedure, namely the RAP strategy, can help students improve their memory of the main ideas and details in the text and make predictions about what the text tells.

Reading is a way of learning that improves students' abilities and knowledge by obtaining meaning from specific texts (Antara \& Aditya, 2019; Mansyur, 2016). Reading is the ability to understand words and the ability to understand what the text is talking about. In other words, it is a collaborative process in which the reader interacts thoughtfully with the text to get the meaning of the sentence or paragraph of the text (Christianti, 2013; Sari, 2019). It is a complex skill that involves the process of seeing and thinking. Reading is categorized as the most complicated process to understand written texts that include the reader's perceptions and thoughts (Astuti \& Istiarini, 2020; Maryani et al., 2017). Students need to understand the text they read to be able to get meaning or understand the text. In reading class, reading activities mostly read reading for comprehension (Muhammad et al., 2019; Pertiwi et al., 2019; Warsihna, 2016). Students' skills in understanding the text will guide them to increase their knowledge and make them able to obtain new information. For this reason, students are expected to have the ability to find out whether it is general or specific information from a text. The findings of previous studies also state that the RAP strategy can help students understand the text (Sukma \& Haryadi, 2016; Suwana et al., 2013).Other research findings also state that the RAP strategy is effective in learning (Mentari, Sukirlan, 
\& Nurweni, 2018; Zahra \& Fitrawati, 2017). There is no in-depth study on the use of RAP strategies to teach reading comprehension in EFL classes. This study aims to analyze the use of the RAP strategy to teach reading comprehension in EFL classes. It is hoped that the RAP strategy can help students understand the text.

\section{Methods}

This type of research is qualitative research. This research is designed in the form of a literature study or literature study. Literature research was conducted to obtain the necessary data through the process of reading library sources. Data sources are taken from electronic books (e-books), research articles, and other relevant sources. The data collected was then analyzed through qualitative data analysis. Data analysis activities are carried out interactively, and the fourth stage is data collection, data reduction, data presentation, and concluding/verification

\section{Results and Discussion}

The Implementation of RAP Strategy, 1) First and Second Meeting. The teacher explains the text, and the teacher trains students to read the text. The teacher asks students to write some tricky words, find the meaning and its synonym. Then, the teacher asks students to make five questions based on the text in which students work in pairs; the teacher selects one group to read their questions. The selected group will choose another group to answer their questions using their own words; the teacher asks students to read another text at home. 2) Third and Fourth Meeting. The teacher gives motivation to students, and the teacher gives another text to students; students will be given time about 10 minutes to read, the teacher asks students to write some tricky words, find the meaning and its synonym, the teacher will select some students to retell the text by using their own words, the teacher asks students to evaluate their learning way in using RAP strategy, asks them the difficulties they faced, their weakness, and the benefit they get.

The RAP strategy has proven to be the right strategy for teaching reading in the classroom for several reasons. The first reason is that the RAP strategy is a reading strategy that supports students to improve their recall of the main ideas and details of a text. The metacognitive strategy based on paraphrasing as the primary point helps students improve their memory about the main ideas and details in the text (Dahlani \& Rahman, 2016; Surayatika, 2018). It requires students to text or break it down into smaller units (paragraphs) to remember them. Paraphrasing is a practical understanding strategy that combines students' skills in asking, understanding, and summarizing (Mentari et al., 2018; Zahra \& Fitrawati, 2017). By doing this activity in reading, students will be helped process information to understand better the text they read. The RAP strategy is an interactive strategy that is very useful for students in reading. The RAP strategy is beneficial for students because: (1) it can make students active readers. The RAP strategy requires students to actively interact with the text or written material to ask and paraphrase the ideas they get from the text itself. In other words, this strategy involves other activities (asking and putting/paraphrasing) in which students are not passively reading the text (Agathi Dian, Kristiantari, \& Ganing, 2015; Warsihna, 2016). (2) Can maintain student concentration. Students must break the text into smaller units (paragraphs) in the reading process to find out the ideas to make students pay attention or focus during reading activities. (3) Can help students to remember information. In addition to the text or breaking it into smaller units, in this strategy, students also emphasize reading the paragraphs intensively in order to find the main idea and details. With text and reading paragraphs in such a way, students will remember what they have read (Surayatika, 2018; Zahra \& Fitrawati, 2017). 
The RAP strategy help students to understand the text and emphasize students' reading comprehension. RAP is one of the strategies that help students to remember what they read. In this strategy, students must read carefully and intensively, asking and paraphrasing or putting the summary to make them more accessible in obtaining information, knowledge, and new vocabulary in entire text or written material (Mentari et al., 2018; Surayatika, 2018). It is a collaborative comprehension strategy that focuses on reading and asking and putting or paraphrasing. Besides, this strategy can also help students retell a story and answer the questions related to the story given in class or task. RAP strategy positively affected students' reading comprehension, especially for inferential comprehension questions (Hagaman \& Reid, 2018; Kemp, 2017). All of the participants in his study, in which three fourth grade students, either maintained reading comprehension or continued improving their reading comprehension two months after the intervention. From this, it can be said that the RAP strategy could increase students' reading comprehension effectively when it is applied in the instructional process. This strategy positively affects low-achieving students (Leidig et al., 2018; Surayatika, 2018). It will make these students able to progress well in their learning, and their comprehension skill is slightly improved.

The RAP strategy provides an opportunity for students to practice the content of the given text. As already mentioned before, the RAP strategy requires students to read the given text and do other activities such as analyzing, inferring, and paraphrasing the meaning of the text (Dahlani \& Rahman, 2016; Surayatika, 2018). Students are facilitated to become independent in comprehending the text. Not only that, but RAP also gives students a chance to increase their reading comprehension in which they can play with their imagination. It will make students more creative in rephrasing. Therefore, RAP is a strategy that develops students' background knowledge besides enhancing their reading skills. The use of the RAP strategy could promote reading comprehension, in which the use of this strategy can make students become active and motivated in participating in the classroom. The RAP strategy is a reading strategy that can be used easily by the teacher in reading class. It is a simple strategy that can adapt or be adapted in many different functions and activities. It can be used in different levels of education (Leidig et al., 2018; Mentari et al., 2018).

\section{Conclusion}

The RAP strategy is an appropriate strategy that teachers can use to teach reading in the classroom because it helps students to improve memory about the main ideas and details of specific texts, interactive reading strategies that offer many benefits for students in reading activities can help students in understanding the text as well as their reading comprehension, offering students with opportunities to practice content, and can be done quickly by teachers in reading classes.

\section{References}

Afrianti, Y., \& Wirman, A. (2020). Penggunaan Media Busy Book Untuk Menstimulasi Kemampuan Membaca Anak. Jurnal Pendidikan Tambusai, 4(2). https://doi.org/https://doi.org/10.31004/jptam.v4i2.578.

Agathi Dian, I. A. A., Kristiantari, R. M. G., \& Ganing, N. (2015). Guru Terhadap Hasil Belajar Pengetahuan Bahasa Indonesia ( Keterampilan Membaca ) Tema Cita-Citaku Pada Siswa Kelas IV SD Desa Peguyangan. Mimbar PGSD Undiksha, 3(1). https://doi.org/http://dx.doi.org/10.23887/jjpgsd.v3i1.5172.

Anjani, S., Dantes, N., \& Artawan, G. (2019). Pengaruh Implementasi Gerakan Literasi Sekolah Terhadap Minat Baca Dan Kemampuan Membaca Pemahaman Siswa Kelas 
V SD Gugus II Kuta Utara. PENDASI: Jurnal Pendidikan Dasar Indonesia, 3(2), 74 83. https://doi.org/https://doi.org/10.23887/jpdi.v3i2.2869.

Antara, \& Aditya, P. (2019). Pengaruh Model Pembelajaran Kontekstual Terhadap Kemampuan Membaca Permulaan Anak. Mimbar Ilmu, 24. https://doi.org/http://dx.doi.org/10.23887/mi.v24i2.21263.

Asna, \& Mimi. (2016). Peningkatan Hasil dan Kemampuan Membaca Intensif Siswa Kelas IV pada Pembelajaran Bahasa Indonesia dengan Model Pembelajaran Word Square di SD Negeri 27 Batang Anai. Jurnal Konseling Dan Pendidikan, 4(2), 74 - 78. https://doi.org/https://doi.org/10.29210/166\%y.

Astuti, \& Istiarini. (2020). Upaya Meningkatkan Kemampuan Membaca Permulaan Anak Usia 5-6 Tahun Melalui Media Puzzle di PAUD Flamboyan Sukasari Kota Tangerang. Ceria: Jurnal Program Studi Pendidikan Anak Usia Dini, 8(2). https://doi.org/http://dx.doi.org/10.31000/ceria.v11i2.2338.

Christianti, M. (2013). Membaca dan Menulis Permulaan Untuk Anak Usia Dini. Jurnal Pendidikan Anak, 2(2). https://doi.org/https://doi.org/10.21831/jpa.v2i2.3042.

Dahlani, A., \& Rahman, R. (2016). Pengaruh Strategi Rap (Read - Ask - Paraphrase) Dan Strategi Kwl (Know - Want To Know - Learned) Terhadap Kemampuan Membaca Pemahaman Siswa Sekolah Dasar Kelas IV. Jurnal Pendidikan Sekolah Dasar (JPsd), 2(1). https://doi.org/http://dx.doi.org/10.30870/jpsd.v2i1.654.

Fitri, J. (2019). Minat Baca Dan Kebiasaan Mencontek Dalam Hasil Belajar Memahami Teks Diskusi Siswa Kelas IX SMP N 1 Pariaman. Jurnal Bahasa Indonesia, Sastra, Dan Pengajarannya, 5(1), 31-38. https://doi.org/http://dx.doi.org/10.26740/jpi.v5n1.p3138.

Hagaman, J. L., \& Reid, R. (2018). The effects of the paraphrasing strategy on the reading comprehension of middle school students at risk for failure in reading. Remedial \& Special Education, 29(4). https://doi.org/https://doi.org/10.1177/0741932507311638.

Kemp, S. E. (2017). RAP: A reading comprehension strategy for students with learning disabilities and concomitant speech language impairments or ADHD. Journal of Education and Training, 4(2). https://doi.org/http://dx.doi.org/10.5296/jet.v4i2.11614.

Lai, A. F., Chen, C. H., \& Lee, G. Y. (2019). An augmented reality-based learning approach to enhancing students' science reading performances from the perspective of the cognitive load theory. British Journal of Educational Technology, 50(1), 232-247. https://doi.org/10.1111/bjet.12716.

Leidig, T., Grünke, M., Urton, K., Knaak, T., \& Hisgen, S. (2018). The effects of the RAP strategy used in a peer-tutoring setting to foster reading comprehension in high-risk fourth graders. A Contemporary Journal, 16(2). Retrieved from https://files.eric.ed.gov/fulltext/EJ1194573.pdf.

Mansyur, U. (2016). Inovasi Pembelajaran Bahasa Indonesia. Retorika, 9(2). https://doi.org/https://doi.org/10.26858/retorika.v9i2.3806.

Maryani, N., Ichsan, M., \& Khairunnisa. (2017). Signifikansi Metode Guide Reading Terhadap Motivasi Belajar Siswa Dalam Teori Membaca Nyaring Guide Reading Method On Students' Learning Motivation In Reading Loudly Lesson. Didaktika Tauhidi: Jurnal Pendidikan Guru Sekolah Dasar, 4(2), 126-139. https://doi.org/http://dx.doi.org/10.30997/dt.v4i2.924.

Mentari, R., Sukirlan, M., \& Nurweni, A. (2018). The Implementation of Rap Strategy to Improve Students' Reading Comprehension. Unila Journal English Teaching, 7(2). Retrieved from http://jurnal.fkip.unila.ac.id/index.php/123/article/view/15280.

Muhammad, Sholichah, \& Aziz. (2019). Pengaruh Budaya Membaca Terhadap Kemampuan Berpikir Kritis Siswa Di SMP Islam Al Syukro Universal Ciputat Tahun 2019. Anragogi, 1(2), 332-343. https://doi.org/http://doi.org/10.36671/andragogi.v1i2.61. 
Ni'matuzahroh. (2015). Efektifitas Strategi Membaca Kolaboratif untuk Meningkatan Pemahaman Bacaan Siswa Sekolah Dasar. Jurnal RAP, 6(2). https://doi.org/https://doi.org/10.24036/rapun.v6i2.6621.

Pertiwi, I. N., Sumarno, \& Dwi, A. (2019). Pengaruh Model Make A Match Berbantu Media Kartu Bergambar terhadap Kemampuan Membaca dan Menulis. MIMBAR PGSD Undiksha, $7(3)$ 261-270. https://doi.org/http://dx.doi.org/10.23887/jjpgsd.v7i3.19412.

Rasyid, H., \& Asrori, M. (2013). Efektivitas Strategi Pembelajaran "K-W-L Teaching Model” Untuk Meningkatkan Kemampuan Memahami Teks. Jurnal Penelitian Dan Evaluasi Pendidikan, 11(1). https://doi.org/https://doi.org/10.21831/pep.v11i1.1418.

Sari, P. A. P. (2019). Hubungan Literasi Baca Tulis Dan Minat Membaca Dengan Hasil Belajar Bahasa Indonesia. Journal for Lesson and Learning Studies, 3(1). https://doi.org/http://dx.doi.org/10.23887/j1ls.v3i1.24324.

Sukma, S., \& Haryadi, H. (2016). Keefektifan strategi REAP dan request dalam pembelajaran membaca pemahaman siswa kelas VIII SMP. Lingtera, 3(1). https://doi.org/https://doi.org/10.21831/lt.v3i1.8476.

Surayatika, D. (2018). The Use of RAP Strategy in Improving Reading Comprehension Of EFL Students. Jurnal Global Ekspert, 7(1). https://doi.org/http://dx.doi.org/10.36982/jge.v7i1.522.

Suwana, I. G. G., Artini, L. P., \& Piscayanti, K. S. (2013). The use of R.A.P. paraphrasing strategy to improve students' reading comprehension at class X.A3 in SMKN 2 Singaraja in academic year 2013/2014. Pendidikan Bahasa Inggris Undiksha, 1(1). https://doi.org/http://dx.doi.org/10.23887/jpbi.v1i1.3859.

Szanto, B. (2020). Reading and Writing Comprehension in the Mother Tongue in the Romanian National Assessment - Objectives, Tests, Results. Technium Social Science Journal, 9. https://doi.org/https://doi.org/10.47577/tssj.v9i1.933.

Warsihna, J. (2016). Meningkatkan Literasi Membaca dan Menulis dengan Teknologi Informasi dan Komunikasi. Kwangsan, 4(2), 67 - 80. https://doi.org/https://doi.org/10.31800/jtp.kw.v4n2.p67--80.

Zahra, F., \& Fitrawati, F. (2017). Teaching Reading Comprehension By Using Metacognitive Strategy: Read, Ask, Paraphrase (Rap) At Senior High School. Journal Of English Education And Teaching, 6(1). https://doi.org/https://doi.org/10.24036/jelt.v6i1.7119. 